\title{
Instability Analysis of Productivity and Production of Cardamom
}

\author{
Jyoti B. Bagalkoti*, A.R.S. Bhat, Siddu Hanabar, J. Megha, T. Rijoy and N.L. Pavitra \\ Department of Agricultural Statistics, College of Agriculture University of Agricultural \\ Sciences, Dharwad - 580 005, India \\ *Corresponding author
}

\section{A B S T R A C T}

\begin{tabular}{|l|}
\hline Ke y w o r d s \\
Instability, \\
Analysis, \\
Production, \\
Cardamom
\end{tabular}

\section{Introduction}

India is known for spice production and export all over the world. India is rightly called as "spice bowl of the world" for its production of variety and superior quality of spices. India produces a wide range of spices and holds a prominent position in world spice production. Because of the varying climates - from tropical to temperate almost all spices grow splendidly in India. From India spices like pepper, cardamom, ginger, turmeric, chilli, tejpat, coriander, cumin, garlic etc. are produced and exported. Black pepper, Cardamom, Ginger, and Chillies are included in the major spices and the rest are considered as minor spices.
India is the world's largest producer, consumer and exporter of spices. The country produces about 75 varieties out of the 109 varieties listed by the International Organization for Standardization (ISO) and accounts for half of the global trading in spices. Spices accounts for 12.98 per cent of the area and 11.5 per cent of total production of horticulture crops in India.

Total spices export from India is 2,26,225 tonnes valued at US\$ 621.78 in 2016 registering a year-on-year growth of 3 per cent. Major importers of Indian spices in 2015-16 were US, China, Vietnam, UAE, Indonesia, Malaysia, UK, Sri Lanka, Saudi Arabia, and Germany. 
Cardamom (Elettaria cardamomum) belongs to the family Zingiberaceae. It is known as the "Queen of Spices". It is a perennial tropical herb plant and grows from a thick rootstalk up to around 6-10 feet. The origin of cardamom is believed to be in the rain forests of the Western Ghats in South India. It is indigenously grown in the evergreen forests of the Western Ghats in South India.

\section{International scenario}

Cardamom is generally produced in the tropical regions of the world. Guatemala is the largest cardamom producing country followed by India in the world. The total world production of this spice is around 55,000 MT per annum. Guatemala is the largest producer of cardamom followed by India and Indonesia. Nearly 41 per cent of World's Cardamom production is in India and more than 30 per cent of the cardamom produced is exported from India.

Even though, Guatemala leads in the World's production it has seen production come down in the past few years due to natural disasters like flood. Besides major producers, cardamom is grown on small scale in Singapore, Netherlands, Nepal, Germany, Sweden, France, Tanzania, Srilanka, Vietnam, Thailand, Cambodia and New Guinea.

\section{National scenario}

India has been a dominant producer of cardamom. It is the second largest producer of cardamom in the world. In 2015-16, as per provisional estimates of Spices Board of India, India's production was around 22,000 MT.

Cultivation of cardamom is concentrated in the ever-green forests of Western Ghats in South India. Kerala, Karnataka and Tamil Nadu are the major cardamom producing states in India. Idukki district in Kerala is known as the major trading centre of cardamom. Kerala is the leading producer of cardamom in the country constituting 78 per cent of the total production from 56 per cent of the area under cardamom in the country.

Instability analysis means the process of analyzing the instability or fluctuation or variation of a commodity from a period to another period. It works as an indicator i.e. it shows how much percentage of instability or variability is going on the commodities under consideration.

\section{Materials and Methods}

This study was based on secondary data and the data was collected from www.indiastat.com and www.indianspices.com. The data for production, productivity and export were collected from 1980-81 to 2014-15. The instability in the production, productivity and export of cardamom was estimated using coefficient of variation and Cuddy Della Valle index.

\section{Co-efficient of variation}

The coefficient of variation is a relative measure of dispersion. The coefficient of variation is obtained by dividing the standard deviation by the mean and expressed in percentage. Symbolically, Coefficient of variation is written as

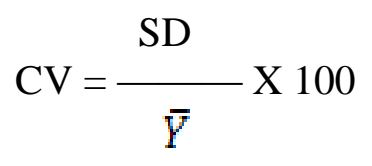

Where,

$\mathrm{SD}=$ standard deviation

$\mathrm{Y}_{\mathrm{i}}=$ cardamom production in $\mathrm{i}^{\text {th }}$ year.

$\bar{Y}=$ mean of cardamom production. 


\section{Cuddy-della valle index (CDVI)}

Cuddy della was used to compute the degree of variation around the trend. This is used when a variable shows some trend which may be linear or non-linear. This Index first detrends the given series and gives a clear direction about the instability. Cuddy-Della Valle index detrend the co-efficient of variation by using coefficient of determination $\left(\mathrm{R}^{2}\right)$.

The Cuddy-della valle index is expressed algebraically in the following estimable form:

Cuddy-Della Valle index $=$ C.V. $*\left(1-R^{2}\right)^{0.5}$

Where,

C.V. $=$ Coefficient of Variation

$\mathrm{R}^{2}=\mathrm{RSS} / \mathrm{TSS}$ i.e. ratio of explained variation to total variation.

This is calculated as,

RSS = Variation explained by explanatory variable.

TSS $=$ Total Variation of cardamom production/productivity

\section{Results and Discussion}

From Table 1 it is clearly observed that, in India the average area of cardamom was 100.048 thousand hectares, production was $12,982.35$ metric tonnes and productivity was $0.128 \mathrm{MT} / \mathrm{ha}$. The maximum area under cardamom cultivation was found to be 121.2 thousand hectares in the year 1989-90 and the minimum area was 81.8 thousand hectares in the year 2007-08. The production of cardamom was recorded highest in the year 2014-15 that is about 24,000 metric tonnes and the lowest production was found in the year 1982-83 that is about 8,000 metric tonnes, meanwhile the productivity was found to be highest in the year 2014-15 that is $0.2295 \mathrm{MT} / \mathrm{ha}$ and lowest in the year 1982-83 that is 0.068 .

In order to examine the extent of instability in production and productivity, of cardamom coefficient of variation and Cuddy-Della Valle Index (CDVI) were worked out. The coefficient of variation measures the absolute variation while coefficient of instability which is also called as instability index measures the variation around the trend.

The coefficient of variation for production and productivity was worked out as shown in Table 2. The results revealed that there was medium instability in both cardamom production and productivity.

At all India level, production and productivity of cardamom showed instability of 30.69 per cent and 35.69 per cent respectively. Here the productivity showed high instability compared to production.

The Cuddy-Della Valle Index resulted that the instability of cardamom production over the periods was 12.62 per cent and the productivity was 11.25 per cent.

Even though, the instability was higher in production than productivity in India the instability was low in both the cases i.e., there was no much variation in cardamom production and productivity and were showing stable growth.

In India, the instability of cardamom production and productivity was stable. As it is a plantation crop, the production will be consistent over the years. But the instability in the production is due to irregular rainfall, incidence of pests and diseases and other climatic factors. 
Table.1 Descriptive statistics for cardamom area, production and productivity

\begin{tabular}{|l|c|c|c|}
\hline \multicolumn{1}{|c|}{ Particulars } & Area ('000 ha) & Production (MT) & $\begin{array}{c}\text { Productivity } \\
\text { (MT/ha) }\end{array}$ \\
\hline Maximum & 121.2 & 24000 & 0.2295 \\
\hline Minimum & 81.8 & 8000 & 0.06818 \\
\hline Mean & 100.048 & 12982.35 & 0.1284 \\
\hline Standard Deviation & 11.48 & 3983.94 & 0.046 \\
\hline
\end{tabular}

Table.2 Instability index of cardamom production and productivity

\begin{tabular}{|l|c|c|c|}
\hline & Production (MT) & Productivity (kg/ha) & Export (MT) \\
\hline $\begin{array}{l}\text { Coefficient of } \\
\text { variation (\%) }\end{array}$ & 30.69 & 35.69 & 97.75 \\
\hline $\begin{array}{l}\text { Cuddy Della Valle } \\
\text { index (\%) }\end{array}$ & 12.62 & 11.25 & 84.09 \\
\hline
\end{tabular}

Instability index of cardamom export was calculated by using coefficient of variation and Cuddy Della Valle index.

It could be seen from Table 2 that the coefficient of variation and Cuddy Della Valle index were 97.75 per cent and 84.09 per cent respectively which indicates that there is high instability in case of cardamom export.

The instability in export of cardamom was instable, that was mainly due to fluctuations in the production in other producing countries and increased value of Indian cardamom in the world markets.

This was mainly due to prices and quantities, which move in similar directions in demand induced disturbances and a significant positive coefficient implies that demand shifts were the main cause of instability in export of cardamom.

\section{References}

Addisu, T.A., 2000. Growth and instability of oilseeds production in Karnataka. M.Sc. (Agri.) Thesis, Univ. Agric. Sci., Dharwad, Karnataka (India).

Karthick, V., Alagumani, T. and Anbarassan, A., 2015. Growth and export performance of ginger in India- An economic analysis. Econ. Affairs, 60(2): 207-214.

Sonal, G., Wankhade, R. N. and Kakde, S., 2010. Growth and instability of chickpea production in Vidarbha region of Maharasthra. Int. J. Comm. Busi. Mgt., 3(2): 172-174.

Thomas, F. K., Arivarasan, S. and David, R. D., 2016. An economic analysis of export performance of black pepper in India. Int J. Curr. Advan. Res., 5(7):1137-1138

www.indianspices.com

www.indiastat.com

www.wikipedia.orc

\section{How to cite this article:}

Jyoti B. Bagalkoti, A. R. S. Bhat, Siddu Hanabar, J. Megha, T. Rijoy and Pavitra N. L. 2019. Instability Analysis of Productivity and Production of Cardamom. Int.J.Curr.Microbiol.App.Sci. 8(07): 1500-1503. doi: https://doi.org/10.20546/ijcmas.2019.807.178 